\title{
The Role of Time in the Theory of Narrative Identity in the Philosophy of Paul Ricoeur
}

\author{
Michal Kumorek $\bowtie$ \\ The Pontifical University of John Paul II, \\ Kanonicza 25, 31-002 Kraków, Poland \\ \michal.kumorek@gmail.com
}

\begin{abstract}
Time has a very important function in considering the identity of a person. It is the factor that brings identity into question. The core of the problem is the question of whether the person is the same as he or she was at another time. The problem of personal identity was one of the most important issues in Paul Ricoeur's philosophy. He considers this problem in the context of time and notes that traditional models of identity as sameness and as selfhood have been entangled in various aporias. He, therefore, proposes two new models of identity that are related in different ways to temporality: character and promise. Character is a model that changes over time through the acquisition or loss of various traits. The promise, on the other hand, is a model that resists the pressure of time attempts to keep a given word. In this way, these two different models create the framework for Ricoeur's concept of narrative identity. In this concept, time enables the development of action in a story. It allows the action to turn around, but it also allows the human being to look at the story of his or her life. Character and promise are models that allow the human being to look at his or her life as a certain temporal entity that is constantly threatened by unforeseen accidents and events but also constantly absorbs them and, through to time, gives the possibility of retrospection leading to synthesis. This synthesis allows us to look at a single life as a whole, belonging to the same person endowed with the character and challenge of keeping a promise.
\end{abstract}

Keywords: Paul Ricoeur, time, identity, character, promise

\section{Article history:}

The article was submitted on 26.02.2021

The article was accepted on 11.08.2021

(C) Kumorek M., 2021

This work is licensed under a Creative Commons Attribution 4.0 International License https://creativecommons.org/licenses/by/4.0/ 
For citation: Kumorek M. The Role of Time in the Theory of Narrative Identity in the Philosophy of Paul Ricoeur. RUDN Journal of Philosophy. 2021;25(3):483 - 494. DOI: 10.22363/2313-2302-2021-25-3-483-494

\section{Introduction}

The problem of a person's identity was solved by ancient and medieval philosophy based on the category of substance, which in the strong premise of the immortal soul was the core of human identity. The contesting the category of substance in modern philosophy resulted in a search for a new path. This research was forced to take into account the context of man's entire life, seeking an answer to the question of whether the old man is the same man he was as a child eighty years earlier. The question of identity, which is related to time and change, was raised again in Paul Ricoeur's philosophy. Ricoeur is a French philosopher who searches for answers to this question and indicates that time can not only weaken a person's identity but can also strengthen it.

The issue of narrative and personal identity appears in Ricoeur's considerations in the context of the experience of time. Ricoeur notes that the subjective experience of time is related to skepticism about the existence of the past and the future. This experience often contradicts the objective time described by the natural sciences. By giving time a narrative character, in which it takes the form of a story, Ricoeur tries to unite these two perspectives of experiencing time. The narrativized time is stretched between the moments of human birth and death. Time constitutes a space in which the identity of the person appears. According to Ricoeur, identity will be revealed in the triad: describe, narrate, prescribe (décrire — raconter - prescrire) [1]. This triad indicates the structure of the analyses that Ricoeur undertakes on the way to building a narrative identity. These are analyses about the language and its grammar that man uses to describe the world and himself. The next level of analysis is human action. Man not only describes the world but also acts in it and he is subject to the actions of others. This relationship with another human being brings a reflection on the narrative identity at an ethical level. At this level the evaluation of human actions takes place. In this context, a man can also discover and strengthen his identity.

\section{The puzzle of the existence of time}

Paul Ricoeur reflects on time inspired by Augustine's 9th Book of Confessions. The French philosopher notes that Augustine was meditating about time in the context of eternity, which reveals many numerous aporias [2. P. 5]. Ricoeur presents Augustine's well-known argument for the non-existence of time, which indicates that the future and the past do not exist and the present does not last. On the other hand, we can talk logically and sensibly about the future and the past. We understand the way we talk about things that will be or already were. Ricoeur points to the core of Augustine's paradox that is the difference in speaking of time. We know that time is, but we can't tell how it is. The core of this puzzle is the difference 
between "that" and the "how." The language in which we talk about time is Ricoeur's argument for its existence. This language of time description reveals a paradox: "How can the positive quality of the verbs 'to have taken place,' 'to occur,' 'to be,' be reconciled with the negativity of the adverbs 'no longer,' 'not yet,' 'not always'?" [2. P. 7].

Ricoeur very subtly shows the strategy of gaining the certainty of time by Augustine. The Bishop of Hippona links the past to memory and the future to expectation. In this way, he finds both the past and the future in the present. However, there are still doubts about the existence of the present, which would have to be the shortest possible moment. The French philosopher notes that Augustine, looking for a solution to this problem, constructs the concept of a threefold present. To prove the existence of the present, Augustine once again returns to the analysis of the existence of the past and the future, which he had previously denied and sought in the present. He points out that we consider things existing in the past to be true and that we expect things to exist in the future. Thus the future and the past are connected to things and actions by Augustine. In this way, our certainty of the past and the future becomes clearer. Augustine found the answer to the question of how time exists. But for Ricoeur's further deliberations, the question of where time exists will be very important.

Memory and expectation are the answer to the question posed by Augustine where the future and the past are. Prediction is possible because we have a "pre-perception" (praesensio) the thing that implies the possibility of their "foretell" (praenuntio). Ricoeur points out that Augustine presented future things in the present by analogy with past things. These things are in the picture of our future as "sign" and a "cause". In this way, the expectation is analogous to memory [2. P. 11]. Ricoeur thinks that although this solution has enabled the future to be integrated into the present, the idea is very fragile. There are three presents in this concept. The first is the present of past things, the second is the present of present things, and the third is the present of future things. However, Ricoeur stresses that this formula ignores the aporias of time. The French philosopher believes that seeing things in the past and the future is the phenomenological conclusion of Augustine's argumentation. Past things are "still" exist in our memory. Future things exist "already" in human souls as images. Ricoeur notes that the new paradox is evidenced by the words "still" and "already". Augustine denies Aristotle's concept of identifying time with movement. On the other hand, Augustine creates the concept of the distension of the mind. This distension of the mind allows things that are not distended to last [2. P. 13-16].

An example that will convince Augustine of the existence of time is the recitation of the verse "Deus creator omnium" [3. P. 119-120]. Bishop of Hippo analyzes the syllables and sounds of this verse taken from Saint Ambrose's hymn. Ricoeur points out that again memory and retrospection appear in Augustine's analyses. These are needed to compare the length of the verse's syllables. Augustine focuses on images in memory, not on sounds themselves. He concludes that even though things pass, they remain in our minds as images of memory [3. P. 18]. 
Ricoeur points out that the recitation draws the reciter's attention to his entire verse. The present takes on the character of intentions and is still active, not just becoming the past. "Man's attentive mind, which is present, is relegating [traicit] the future to the past. The past increases in proportion as the future diminish until the future is entirely absorbed and the whole becomes past" (27:36) [3. P. 19]. Ricoeur turns to three words used in Augustine's analyses: "expectation [expectat], attention [adtendit; this verb recalls the intentio praesens], and memory [meminit]" [3. P. 19]. These are functions that oscillate between passivity and activity. These functions will be seen in Ricoeur's analysis of narrative theory.

\section{The puzzle of the existence of identity}

The problem of the passing of time provokes the question of personal identity, which Ricoeur analyzes in modern philosophy. This perspective is important for Ricoeur's further considerations. Time plays a very important role in this analysis because he constantly questions the identity of a person. Ricoeur pays special attention to the problem of identity in the thoughts of British philosophers. John Locke, David Hume, and Derek Parfit were looking for an answer to the question of identity, which is constantly struggling with the challenge of time. Therefore, the issue of time occurs with all attempts to define a personal identity.

John Locke considers identity to be the opposite of the idea of difference. He indicates that the idea of identity appears in our mind when we compare a thing with itself at another time. When we look at it for a while, we're sure it's still the same thing. This type of identity is defined as numerical identity. But if a longer period passes between our perceptions, we lose our confidence in the identity of the thing [4. P. 298]. Ricoeur indicates that in addition to numerical identity, there is also qualitative identity. This type of identity allows us to say that two numerical different things are the same because of their undifferentiated similarity [5. P. 116-117]. Locke allows for some changes despite the permanence of identity. A growing plant, a maturing animal, or a human being will retain its identity by sorting out the changes that take place. This type of identity is defined as uninterrupted continuity between the first and last stages of development and change of the same thing or organism. Locke distinguishes between human identity and a person's identity. The first is reduced to changes occurring in the human body. The second is associated with the awareness and thinking of a person [4. P. 305-306]. A person recognizes himself as the same. Ricoeur notes that consciousness is temporal and extends to the person's entire past. The retrospective is an inherent feature of consciousness [5. P. 125-126]. The connection between human identity and memory is also exposed to many challenges of time, as Locke himself has already noticed. These problems are highlighted much more clearly by David Hume.

For Hume, the idea of identity is created only through belief and imagination. This idea is helpful in our lives, but it does not express the truth about a person who is a bundle of changing impressions [6. P. 393-397]. Ricoeur draws attention to Hume's idea, which compared personal identity to the unity of the Commonwealth 
or republic. The bonds of association continue to exist despite the changes in the republic's members. Successive generations are being replaced by those leaving, and the republic continues thanks to certain relations and laws [5. P. 127-128].

Skeptical conclusions about personal identity are brought to extremes by Derek Parfit. He was a British ethicist who wrote in the same years as Ricoeur. Parfit believed that personal identity is only "Further Fact View" [7. P. 209-210]. His theory that "personal identity is not what matters" [7. P. 282-283] is based on the analysis of the links between physical and mental events over time. He excluded the first-person experience from his analysis. In this way, he concluded that our existence is reduced to the existence of our brains and bodies, the occurrence of mental and physical events [7. P. 216-217]. Ricoeur shows that Parfit ignores the temporal and historical aspects of his analyses [5. P. 136]. Introducing considerations of a person's historicity and timeliness into the identity debate will allow Ricoeur to take a renewed look at the problem of a person's identity. The aspect of time that questioned a person's identity will be used by Ricoeur to build a narrative identity. In this identity, important roles have a character and a promise that are questioned by time in other ways.

\section{Character and keeping one's word in the perspective of time}

Ricoeur will search for a narrative identity by comparing his proposed models: character and keeping one's word. These models are in relation to traditional models of identity: sameness (Latin: idem) and selfhood (Latin: ipse). Sameness is a model that includes categories of numerical identity, qualitative identity, and uninterrupted continuity. In this model, an object or person is recognized as the same over time. However, the reduction of identity to this model is entangled in numerous aporias, as shown by the analysis of the identity problem in modern philosophy. The French philosopher emphasizes the importance of the selfhood model, which seems to open up a perspective to describe identity detached from substantiality. Identity as selfhood refers more to the inner relationship with oneself as opposed to sameness. Selfhood is an identification that I make by recognizing the same person as myself. This approach allows Ricoeur to reach beyond the question of "what I am?" and seek an answer to the question of "who I am?" [5. P. 115-118].

Character is a set of distinctive features that is similar to models of identity as sameness. A character owner is a person who can be recognized by others. On the other hand, a person may perceive himself as the owner of his character. Moreover, a person can shape character traits with time, in a particular place, history, family, society, or culture [8. P. 215]. Ricoeur defines character as "the set of distinctive marks which permit the reidentification of a human individual as being the same. By the descriptive features that will be given, the individual compounds numerical identity and qualitative identity, uninterrupted continuity, and permanence in time." [5. P. 119] The character is temporary. This timeliness gives the character history. This history is compared by Ricoeur to the accumulation of layers of character in the process of sedimentation. These layers are put aside over the years and make it possible to notice the relationship between a person's traits and behavior today and 
in the past. New habits are accumulated like layers on the old ones, allowing for change while maintaining a certain connection. The history of these changes is open for the future, and the character itself is not complete. A person is not recognized only by the stable traits of character, but rather by the historical moments in which some traits have been acquired or lost [9. P. 135].

Ricoeur bases his concept of changing character traits on the theory of the virtues created by Aristotle. The virtue that is part of the character can be acquired by action or lost by abandoning the relevant actions. The act of a subject is linked to time and thus enters into the narrative framework. A person can be seen and identified in time as the same person who acts in a similar way, who trains in some virtue, or falls into a flaw. The character traits contain habits that have already been acquired and those that we are just acquiring. This dynamic is made possible by time and allows or even forces changes in the character traits [10.1112a 13,1139a $23-24,1144 b$ 27].

Keeping one's word is a second model of identity proposed by Ricoeur. It is based on faithfulness to the word given to someone else [5. P. 118]. A feature of keeping one's word is resistance to change despite the passage of time. Keeping one's word expresses fidelity as keeping the self despite many other changes. Keeping one's word as the model of identity is part of being selfhood, the dimension of "who?" Ricoeur also makes a distinction between the continuity of changes in character traits over time and the challenge of not changing the promise. In the first case, the French philosopher speaks of maintaining, a certain continuity of the traits of character that we have acquired. By these traits, we can be recognized as the same people. In the case of keeping one's word, Ricoeur points out the permanence of its duration. The permanence of a promise is different from the permanence of character. It is a constancy that resists the change of time, just like a faithful friendship that lasts despite the turbulence of life. In Ricoeur's philosophy, keeping one's word is a certain beginning, and faithfulness to the promise will have a character of permanence in time.

Time is fundamental to the model of keeping one's word. On the one hand, time is the perspective for making a promise. The promise includes the intention to put loyalty to self above giving in to outside desires and obstacles. In this context, Ricoeur recalls the analysis of fidelity to the promise made by Gabriel Marcel. He points to an alternative at the moment of making a commitment that presupposes either the unchangeability of feelings and desires to fulfill it or the agreement to fulfill it despite the variability of primary motivations and dispositions. Both parts of the alternative represent a reduction of fidelity, which in the first case is a lie to himself and in the second a lie to another. The answer to this paradox is a commitment to which I want to be faithful. Marcel defines fidelity as availability and disposability [11. P. 48-50]. Ricoeur stresses that the moment of intention that is a commitment presupposes some "you" as the recipient of the promise. The promise is dialogical and based on the principle of reciprocity called the Golden Rule. The person making the promise and the person accepting the promise are in an asymmetrical relationship. The addressee of the promise has the right to count on me 
and expect an answer from the person making the promise [5. P. 266-268]. Time is the space that constantly puts the promise to the in which a given word can be kept or broken. Time is the dimension of the future that seems to be full of uncertainty and possible unpredictability. Ricoeur refers to Hannah Arendt, who pointed out that the promise of man gives more predictability to the future. But no promise can define all the possibilities that the future holds within it [12. P. 237, 243-244].

\section{The person in the narrative}

The new models of personal identity proposed by Ricoeur are an element that, once introduced into theory, enables the formulation of a narrative identity conception. This concept is an attempt to respond to the paradoxes of personal identity in modern philosophy. The distance between the story and the experience of living in a concept will be crossed in the narrative identity. The French philosopher will try to show the relationship in which fiction shapes our biological life in a new conception of identity [13. P. 37]. He refers to the poetics of Aristotle in his analysis. Ricoeur agrees that the art of storytelling requires that the facts and events are properly arranged in quantitative and qualitative order [14. 1447a]. He also refers to Wilhelm Dilthey, who introduced the term Zusammenhang des Lebens. This term indicates the connection between the context of life and the history of that life. This story becomes coherent by organizing various events and facts. The identity of the person will be linked to the identity of the storyline. Ricoeur describes the narrative identity in dynamic terms as a result of the dispute between what is compatible and what is incompatible. Compatibility is the principle of order and sequence of events and incompatibility is the principle that exposes that compliance to danger by introducing various random events. These random events disturb the initial order but move the plot forward [5. P. 141]. The plot has the power to unite the incompatible. Ricoeur explains that incompatibility can be shown in harmony from a retrospective point of view.

The story about human life has the power to unite and explain different events, cases, and turns of action. The story is told in such a way as to explain its key elements: why is someone a hero or why has someone changed his or her mind? This is done without contradicting previous events in which the hero was involved. The story also does not contradict the person's previous beliefs, which may have changed later. The story allows all these changes and modifications because there is an opportunity to look at them from a different perspective. According to Ricoeur, the refiguration allows us to look at history and the person from history from a new perspective. This reconfiguration is a le-lecture, a rereading of a person's life story. Ricoeur's rereading of life compares to a man who talks to a psychoanalyst. The role of a psychoanalyst is to help a person understand difficult fragments and incomprehensible parts of life. This is done by integrating them into a coherent story. The man can then recognize his self-constancy. Ricoeur points out that Freud calls this process "working-through" (Durcharbeitung) [15. P. 245-246]. The French philosopher stresses the ordering function of time in the Durcharbeitung. Time makes it possible to understand the unexpected course of events and random 
cases, which is incorporated into the story heading towards the end. Time brings the moment when we can look at our life from a different perspective and with a new understanding. This le-lecture has a constitutive dimension for the identity not only of the person but of the whole community, which builds its identity based on a constant reading of history [16. P. 88-98].

\section{The practical dimension of the narrative}

The action of the person in the story is the next step in developing Ricoeur's concept of narrative identity. The theory of narrative identity is directly related to the theory of action. The person acts and at the same time is subject to the actions of others [5. P. 144-145]. The French philosopher stresses that Aristotle in Poetics understands action as a set of events that shape the subject in the narrative. The first groups of activities distinguished by Ricoeur are practices. Practices are different actions than basic activities, which are simple gestures, attitudes, and basic bodily activities that we perform because of something or someone. Examples of practices are crafts, arts, and games. Ricoeur notes that practices form a series of activities and are contained within each other. These practices interact with other people's actions. This reference to the actions of others can take various forms such as cooperation, competition, or conflict. Ricoeur complements the theory of practice by emphasizing that not acting or allowing another to act is also like a type of action and it is included in the field of practical action. An act that is subjectively understood as non-action comes into numerous interactions. Failure to act can be a consequence of the action of another. The non-action may also cause the suffering of others as well as their actions. In conclusion, Ricoeur points out that "In fact, every action has its agents and its patients" [5. P. 152-157]. Also, the activity that is refusing can imply another action.

Ricoeur also considers the relationship between storytelling and action at a higher level of the organization, which concerns a person's entire life. These holistic projects of existence were called life plans by the French philosopher. Life plans are in a dynamic relationship with practices. The French philosopher notes that there is a double movement in the practical field of action. On the one hand, life plans are created by basic practices and activities which become complex and merge into cause and effect sequences. On the other hand, life plans influence practices. Life plans allow a person to look at practices and understand them from the perspective of history [5. P. 157-158]. Life plans are not only structures that integrate the practices of a person, but also have the role of transition between those practices and the unity of life. The unity of life is Diltheyan "the connectedness of a life", on which Alasdair MacIntyre imposes narrative structures [17. P. 218-220]. This narrative unity of life is subject to both specific practices and undefined life plans, while at the same time influencing them through the person's natural desire to outline the overall project of life at its various stages. MacIntyre gives the concept of life a narrative perspective because only life that is summarized as a story provides the foundation for its ethical dimension. Ricoeur notes the similarity of his analyses with the Scottish philosopher, noting, however, that MacIntyre focuses on 
everyday life and does not enter the field of life-impacting literary fiction. Meanwhile, this fiction is a fundamental issue for Ricoeur. Fiction makes it possible to combine action with a person in infinite imaginary variations. The whole perspective of the future opens up with life plans. These life plans include expectations, projects, and predictions, which include a concern for the future and allow for a narrative fusion of retrospection and prospectus.

\section{The ethical dimension of the narrative}

Ricoeur's concept of narrative identity is inextricably linked above all with ethical theory. Axiology appears already at the level of language use. The grammar of even the adverbs themselves (mine, yours, ours, yours, etc.) expresses the nature of possession and indicates the value [18. P. 84]. Ricoeur answers Parfita's thesis that "personal identity is not what matters" already at the level of language analysis. The French philosopher notes that Parfit, although he postulates giving up the firstperson point of view, cannot do so by formulating his theories himself [5. P. 137]. The narrative is also the space for exchanging experiences. These experiences are not only observations but also contain valuable judgments, responsibilities, actions, and related objectives. Ricoeur notes that fiction opens up new ways of giving value to the actions of characters. The moral judgments in the narrative are discovered by the reader, the narrator, and the person from the story. The actions taken in the narrative are evaluated similarly to the subject of these actions. The variety of possible actions in fiction also causes a variety of possible axiological judgments [15. P. 163-164].

The French philosopher points out that every story implies moral judgments. Even a historiographical story is not completely free from these evaluations. A historian has to choose which story he wants to research. Moreover, such a story somehow belongs to those who have lived before [19. P. 251-260]. This claim takes on a special dimension when it concerns the history of the victims. The obligation not to forget takes on a moral dimension through history such as Auschwitz [15. P. 186-188] $]^{1}$. At the same time, Ricoeur notes the danger of manipulating the narrative. This manipulation is particularly relevant to history and is based on collective memory. A community that has experienced a difficult and painful history is particularly vulnerable to manipulation. Ricoeur says that some facts can be suppressed, questioned, or, on the other hand, these facts can be absolutized and accentuated on many occasions. The French philosopher considers that both forms of manipulation falsify the identity of an entire community or group of people [19. P. 141-145].

Ricoeur notes that the theory of narrative identity is particularly close to the ethical theory in the model of promise. He refers to Emmanuel Lévinas, who links the preservation of self to the response of another person [22. P. 113-116]. Ricoeur

\footnotetext{
${ }^{1}$ More about collective memory as a duty of justice: Ricoeur P. "Critique and Conviction. Conversations with François Azouvi and Marc de Launay" [20. P. 116-127]; Duffy M. "Paul Ricoeur's Pedagogy of Pardon, A Narrative Theory of Memory and Forgetting" [21. P. 48 — 51].
} 
believes that the character of a person also acquires an ethical character by submitting to the narrative. Depending on whether the person is striving for a good life, a character can take on virtues. However, keeping his word is crucial for finding and preserving selfhood. A promise has a dialogical dimension, so it is always made to some other person. This person may require me to keep my word. I, too, can feel bound by promises, even when, after many years, I am no longer recognized by the person I gave my word. The promise as a friendship that continues despite changes and breakups is a favorite example given by Ricoeur. On the ethical level, the model of promise provides an answer to the question "who am I?". This answer is the cry "here I am" which is also the answer to a moral obligation. This answer is related to the choice of action or life and to care for another person. In this answer, a man finds his identity as selfhood. At this level, one more misconception in Derek Parfit's argumentation is revealed. Ricoeur points out that the resignation from admitting the identity of a person does not imply a lack of it, but indicates its crisis. The appearance of another person is the moment when this crisis can be overcome and identity can be confirmed anew.

\section{Conclusion}

The issue of time is important to Ricoeur at all stages of his consideration of narrative identity. Moreover, the idea of narrative identity has its source in reflections on the existence of time. Ricoeur refers to Augustine who considers how the experience of the past and the future acquires meaning and certainty while the verse of the psalm is recited. This recitation already takes on a certain narrative character, which grows with the reading of the whole psalm and its frequent repetition. In this way, time becomes the foundation of the narrative.

Ricoeur considers the problem of personal identity in these perspectives of time and narrative. In modern philosophy, the passage of time was a factor that questioned the existence of personal identity. Concepts of personal identity revealed many aporias when they were subjected to the time factor. These paradoxes are particularly evident in the philosophy of John Locke, David Hume, and Derek Parfit. The category of time, which seems to undermine the certainty of personal identity, is used by Ricoeur to find that certainty. Ricoeur does this by applying narrative theory. By transferring a person's life and the question of his or her identity to the narrative plane, it is possible to look at these problems from a different perspective.

The character and keeping one's word are two models of identity proposed by the French philosopher. They are linked to time in a completely different way. Character is changeable and can be shaped by man. A man's character traits change when he seeks a good life. Time allows for character changes that are arranged in some order. On the other hand, a promise is based on the passage of time and is paradoxically questioned during this time. This paradox of promise is a challenge for a man who discovers and strengthens his identity in keeping his word to another man. These models of identity are used in the theory of narrative identity by Ricoeur. A person can describe reality and himself but also acts and influences 
others with his actions. In this way, the problem of identity will be transferred to the plane of action and ethical evaluation. In these dimensions, the identity of a person is revealed. This happens especially in contact with another human being, which implies a model of promise. Time is a factor that can confirm the faithfulness of a promise. Time also allows a person to view life from a different perspective. It allows a person to look at their life and reinterpret their various incidents and turns of events. Time allows for changes and enables the search for moments in which a person confirms his or her identity.

\section{References}

[1] Kemp P. Narrative Ethics and Moral Law in Ricoeur. In: Wall J, Schweiker W, Hall DW editors. Paul Ricoeur and Contemporary Moral Thought. New York, London: Routledge; 2002. p. 32- 46.

[2] Ricoeur P. Time and Narrative. Vol. 1. Chicago and London: The University of Chicago Press; 1984.

[3] Augustine. The Confessions of Saint Augustine. Grand Rapids, MI: Christian Classics Ethereal Library; 1999.

[4] Locke J. An Essay Concerning Human Understanding. Book II. Global Grey; 2019.

[5] Ricoeur P. Oneself as Another. Chicago, London: The University of Chicago Press; 1992.

[6] Hume D. A Treatise of Human Nature. The Floating Press; 2009.

[7] Parfit D. Reasons and Persons. Oxford: Clarendon Press; 1984.

[8] Muldoon S. Mark. Tricks of Time, Bergson, Merleau-Ponte and Ricoeur in the Search of Time, Self and Meaning. Pittsburgh: Duquesne University Press; 2006.

[9] Drwięga M. Paul Ricoeur daje do myślenia. Bydgoszcz: Wydawnictwo Homini; 1998.

[10] Aristotle. Nicomachean Ethics. Oxford: Cambridge University Press; 2004.

[11] Marcel G. Being and Having. Glasgow: The University Press; 1949.

[12] Arendt H. The Human Condition. Chicago, London: The University of Chicago Press; 1998.

[13] Ricoeur P. Filozofia osoby, wykłady z filozofii współczesnej im. Ks. prof. Konstantego Michalskiego CM. Kraków: Wydawnictwo Naukowe Papieskiej Akademii Teologicznej; 1992.

[14] Aristotle. The Poetics. Oxford: Clarendon Press; 1962.

[15] Ricoeur P. Time and Narrative. Vol. 3. Chicago, London: The University of Chicago Press; 1988.

[16] Pellauer D. Ricoeur, A Guide for the Perplexed. London: Continuum International Publishing Group; 2007.

[17] Maclntyre A. After Virtue: A Study in Moral Theory. Notre Dame, Ind.: University of Notre Dame Press; 2007.

[18] Kaplan M. David. Ricoeur's Critical Theory. Albany: State University of New York Press; 2003.

[19] Ricoeur P. Memory, History, Forgetting. Chicago, London: The University of Chicago Press; 2004.

[20] Ricoeur P. Critique and Conviction. Conversations with François Azouvi and Marc de Launay. New York: Columbia University Press; 1998.

[21] Duffy M. Paul Ricoeur's Pedagogy of Pardon, A Narrative Theory of Memory and Forgetting. London, New York: Continuum International Publishing Group; 2009.

[22] Levinas E. Otherwise than Being or Beyond Essence. Dordrecht: Kluwer Academic Publishers; 1991. 
About the author:

Kumorek Michat — Ph.D. student in Philosophy, The Pontifical University of John Paul II, Kraków, Poland (e-mail: michal.kumorek@gmail.com).

\title{
Роль времени в теории нарративной идентичности в философии Поля Рикёра
}

\author{
Михал Куморек $\bowtie$ \\ Папский университет Иоанна Павла II, \\ Польша, 31-002, Краков, ул. Канонича, 25 \\ \michal.kumorek@gmail.com
}

\begin{abstract}
Аннотация. В исследовании человеческой идентичности важнейшая функция отводится времени. Время - тот фактор, который ставит под сомнение идентичность. Суть проблемы заключается в вопросе о том, является ли человек тем же самым, каким он или она были в другое время. Проблема персональной идентичности была одним из важнейших вопросов в философии Поля Рикёра. Он рассматривает эту проблему в контексте времени и отмечает, что традиционные модели идентичности как тождества и как самости оказались перемешаны в различных апориях. Поэтому он предлагает две новые модели идентичности, которые по-разному связаны с временностью: это характер и обещание. Модель идентичности как характера меняется с течением времени вследствие приобретения или потери различных черт характера. Обещание же, напротив, - это та модель, которая сопротивляется натиску времени в попытке сдержать данное слово. Таким образом, у Рикёра эти две разные модели создают основу для концепции повествовательной идентичности. Согласно его концепции, время делает возможным развитие действия в истории. Оно позволяет обернуть действие иначе, а также дает человеку возможность взглянуть на историю своей жизни. Характер и обещание - это модели, позволяющие человеку увидеть свою жизнь как некую временную сущность, которой постоянно угрожают непредвиденные несчастные случаи и происшествия, но она также постоянно поглощает их и, спустя время, даёт возможность ретроспекции, ведущей к синтезу. Этот синтез позволяет нам взглянуть на одну-единственную жизнь как на целое, которое принадлежит одному и тому же человеку, наделенному характером и способностью сдерживать обещание.
\end{abstract}

Ключевые слова: Поль Рикёр, время, идентичность, характер, обещание

\section{История статьи:}

Статья поступила 26.02.2021

Статья принята к публикации 11.08.2021

Для цитирования: Kumorek $M$. The Role of Time in the Theory of Narrative Identity in the Philosophy of Paul Ricoeur // Вестник Российского университета дружбы народов. Серия: Философия. 2021. T. 25. № 3. C. 483-494. DOI: 10.22363/2313-2302-2021-25-3-483-494

\section{Сведения об авторе:}

Куморек Михал - аспирант (PhD студент), Папский университет Иоанна Павла II, Краков, Польша, (e-mail: michal.kumorek@gmail.com). 